\title{
Job Methods - An Approach to Increase Human Resource Productivity in Pandemic COVID-19 (A Case Study of Parason Group, India)
}

\author{
Dr. Meenakshi Tyagi ${ }^{1} \quad$ Kuldeep Tyagi ${ }^{2}$ \\ 1. Assistant Professor, KIET School of Management, KIET Group of Institutions, Delhi-NCR, Ghaziabad- \\ Meerut Road, NH 58, Ghaziabad, Uttar Pradesh 201206 \\ 2. Director, Kaizen Institute India (SAIN), Kaizen Institute India, 207 - 208 Abhijeet I, Ellisbridge, Near \\ Mithakhali Six Roads, 380006 Ahmedabad, India
}

\begin{abstract}
Apart from multidimensional challenges and fierce competition, COVID-19 has created immense stress on manufacturing industries to work with limited human resources due to social distancing and other safety measures. During this tough time (COVID-19) companies are in great pressure to manage their costs, one of the significant cost is labour cost. Labour productivity is a division of worth of goods or services produced and labour hours used to produce that, thus productivity improvement can be done by producing more with same labour hours or producing same with less labour hours. There is a process of producing goods or services, each process may have one or more activity and each activity will have some methods to accomplish. Each process is also having its completion time which ultimately depends on number of activities and methods. If somehow the number of activities can be reduced or methods to accomplish the activity can be simplified in terms of easiness and less time without impacting quality of products or services, the completion time of that process will be reduced and eventually a gain in productivity will be achieved to help companies to be more productive and profitable without addition of manpower. The facilities and technology enhancement what the manufacturing world is enjoying today, is the result of improvement in production methods, e.g. automobile, mobile phones, laptops, home appliances etc. The TWI - Job Methods program is a structured program to identify and eliminate non value adding activities and to improve the existing methods of doing a job with available resources. Job Methods programme is focused on making the methods of work smarter and better. TWI - Job Methods is the best tool for involving all supervisor and workers in an organization for improvement activities. It also helps to involve the supervisors with the workforce and bring out collaborative solutions for different obstacles that occurs while working. Job Methods programme also provides a systematic improvement proposal to management to communicate so that decision making about new methods or process can be effective and quick. The case study had completed during Jan and Feb 2020 and focused on the practical application of Job Methods (JM) to improve productivity by using same number of human resources in producing refiner plates in a leading paper and pulp machine manufacturing company in India. TWI-JM technique is very relevant during tough time (COVID-19) when manpower availability is a concern and raise in productivity is required.
\end{abstract}

Keywords- Training within industry (TWI), Job Methods (JM), Job Breakdown Sheet (JBS), Inner Diameter (ID), Outer Diameter (OD)

DOI: $10.7176 / \mathrm{EJBM} / 12-16-01$

Publication date:June 30th 2020

\section{Introduction}

The concept of TWI (Training within Industry) emerged during World War II in US, where the able bodied manpower from the companies drafted in to the military which resulted in shortage of skilled workforce in the companies. Companies were forced to recruit unskilled workers many of them were uneducated, ladies, farmers and other people with normal skill set. The recruitment was huge and there was a need to produce quality products specially weapons and ammunition in most imperativeness to maintain the supply to win the war. This new and unskilled workforce was exposed to complicated processes with an expectation of producing products as per standard which they couldn't. To solve this problem United States Department of War created TWI during 1940 to 1945 . TWI primarily started to serve the purpose of consulting to war allied companies later on become the most effective technique of skill transfer, process simplification and relationship building across the globe. Post war, famously known as four Horsemen, Mike Kane, Channing Dooley, Walter Dietz and Bill Conover established the TWI foundation to spread the practice across Europe and Asia. TWI equally received in other parts of world including Japan and India, in Japan due to war agreement of not to own army and any ammunition company the people who used to work there were forced to work in other companies, Japan used TWI to train these people on new processes with new products.US discontinued this practice after world war but Japan continued to practice, after many years when Donald A. Dinero published the book on TWI, it came known to the world, still in India we have very limited practitioners of this technique but slowly-slowly picking up. TWI is three pronged 
approached, first one is called Job Instruction (JI) which focuses on rapid skill transfer, second is Job Methods (JM) which focuses on to improve existing processes by using available resources and third one is Job Relations (JR) which focuses on solving personal problems in analytical way to avoid distraction of employees from targeted goals. Under the TWI framework, the Job Methods (JM) is an approach which helps in improving existing methods of doing a job and changing the paradigm of individuals that the existing methods can be improved without resource limitations to improve overall process effectiveness. The JM provides an easier, effective and productive method of doing the same job in a smarter way.

Donald A. Dinero, explained in his famous book - "Training within industry: The foundation of lean" (year 2005) that using JM, companies can taught their employees how can they improve their processes using available resources Patrick Graupp \& Robert J. Wrona defined JM in their book "The TWI Workbook: Essential Skills for Supervisors" (year 2006), as the simplest way to simplify the processes by studying, analyzing and elimination of non-value adding activities in working methods. Again Donald A. Dinero in his book "The TWI Facilitator's Guide: How to Use the TWI Programs Successfully" (year 2016) emphasized on customization of JM program to suit various cultures but without compromising on original principles, also he explained what TWI and JM must give us the answer of why should we not do it (all non-value adding activities)? Once it's clear then removal of that step is easy and a series of these steps eventually will lead to a shorter process without compromising intended purpose. Charles R. Allen, in his book "The Instructor: The Man and the Job" (2018) focused relationship between man his job and beautifully emphasized about standardization of job through JM to make work enjoyable and significant. Kaizen Institute India (a consulting company) has designed special module on JM, through which they have successfully simplified many processes in a very short period of time, resulting a more productive workplace. JM aims to reduce or eliminate the non-value adding activities to speed up the process, not on increasing the working speed as it can cause mistakes, supervisors are solely responsible for their departmental improvement which can be done using JM. The objective of JM can be defined as "A practical plan to help you to produce greater quantity of quality products in less time by making the best use of the Manpower, Machine \& Materials now available", further in detail can be explained as:

- A practical plan : method that anyone can use easily on daily basis

- To help you : not telling answer, but enabling to discover best solution

- Produce : the method is designed to facilitate production of product, not decide which product to produce

- Greater quantity : increasing production of products that you already make

- Quality products : at a minimum, not increase at the expense of reducing the level of quality $\&$ at best

- In less time : the quantity made per unit of time should increase

- By making the best use : optimizing the process by eliminating wasteful activities

- Manpower, Machine \& Materials : consider all resources

- Now available : existing resources

\begin{abstract}
About The Company
The Parason Group has been leading the market of manufacturing and supplying paper and pulp machinery and its spare parts. Parason started its first research unit for pulp and paper machinery in the Year 1977. Parason Group has total 8 units in Aurangabad, Maharashtra. Parason also have specialization in Refiner Discs and these are one of the best disc available for Paper mills across the globe. Parason Group is involved in manufacturing of a wide range of products used by Kraft, Tissue, Writing, Printing and Hard Board Paper Mills. Due to high quality standards and timely supply, Parason products are blindly used in various Indian paper mills. Parason have worldwide client base and having majority market in Germany, USA, France, Thailand, Italy, Brazil, Spain, Portugal, Philippines, Indonesia, and Bangladesh, Parason serving more than 60 countries across the globe.
\end{abstract}

\title{
Background of the Study
}

In the machining unit of Parason group, various machining operations like drilling, grinding, boring are performed to produce the refiner plates. The refiner plates are used in various paper and pulp manufacturing companies in their pulp refining machines. The production requirement of these plates is very large as it is used in bulk. In the process of making the refiner plates material removal operations are carried out at a large scale on various conventional machines like lathe machines and drilling machines. The company was in a great hurry to increase the production capacity of the same by adding machines and manpower to meet existing and future demand, then they came to know about "TWI-JM" approach and decided to give it a try. The study was done during Jan - Feb 2020 .

\section{Implementation Approach -Job Methods (JM) Technique}

The method of doing work plays a crucial role always but significantly in large scale production. Job Methods $(\mathrm{JM})$ is one of the modules of the TWI focusing on improving the shop floor method of doing work. It focuses 
methods simplification. The Job Methods program was developed in order to provide the management with a tool, by which supervisors \& workers could acquire skill in improving methods thus resulting in productivity improvement. Job Methods methodology aims in achieving maximum number products with better quality within the shortest possible time duration. As per the Job Methods methodology, the supervisor can develop a new simplified method of doing existing jobs with the team. A team including supervisor and lathe operators was formed, they were trained on the Job Methods techniques and the project was completed by following 4 Steps of JM:

1. Breakdown the job

2. Question every detail

3. Develop new method

4. Apply new method

\section{Breakdown the Job}

As the name itself suggests, this step includes the breakdown of each and every step which is performed currently while doing a job. It includes each and every single activity performed while doing a job and breaking these activities in steps. It should also include quality checks, delay or any waiting during job accomplishment. The three elements to be taken care of, while breaking the job are as follows

- Material handling

- Machine work

- Hand work.

It is required to make notes regarding each activity which includes all the distances travelled, tolerances taken or to be taken, safety needs, scrap material, time used, weights, etc. Along with this, also list all the long reaches, holdings, stoppages, bending, or extra difficult moves.

These details help to collect all the facts regarding the job in a systematic manner. These details are completely reliable and accurate as these are based on the current method and collected during real time. A standard job breakdown sheet format should be used to avoid any misunderstanding. In making refiner plates the operations including inner diameter (ID) machining and outer diameter (OD) machining is performed for material removal from refiner discs. These operations are carried out on conventional lathe machine. The detailed job breakdown of all these machining processes was made in which individual activities were noted down with consideration of all 3 elements (material handling, machine work, and hand work). The notes were also made with respect to time, distance and weight maintained in the job breakdown sheet (figure- 1)

As per job breakdown sheet (Figure 1) the breakdown of the present method of doing job listed and found that there were total 91 activities involved with a total time of 55 minutes to accomplish the same. After this the next step of Question every detail conceded.

\section{Question Every Detail}

Any scope of improvement starts with a questionable attitude and with a paradigm that any existing state can be improved further. A successful improvement in any method depends upon the questioning capability of the improver for the current method. No method is optimum for a longer run and hence it can be questioned every now and then. Every on-going activity is questionable; this provides the scope for improvement, always remember this. Questions should be asked as mentioned in table 1.

During the questioning phase, certain points need to be taken under consideration for getting the exact scope of improvement which are: Machines, Equipment, Tools, Product Design, Workplace Layout, Movement, Safety and Housekeeping etc. Thus in the mentioned manner, all questioning was done on all activities (noted during job breakdown sheet- figure, 1) with taking utmost care for the parameters. After that, the exercise for developing new methods based on questioning input was done.

\section{Develop New Methods}

Productivity can be increased only when number of activities in a process are eliminated, combined, rearranged, or simplified. For every new method, there has to be a lot of thinking processes involved behind it. ECRS technique was used in "Develop the New Method", ECRS is elaborated below:

- $\quad$ E - Eliminate unnecessary activities

- $\quad$ C - Combine activities whenever possible and practical

- $\quad \mathrm{R}$ - Rearrange activities for better sequence

- S - Simplify activities so that they are easier and safer to do

The ECRS technique looks simple and easy to understand however very crucial when it comes to implementation. As per the ECRS technique, the activities which are eliminated by asking questions focusing on 'Why' and 'What' are marked as red cross (figure, 1-job breakdown sheet). The other activities which are Combined, rearranged and simplified are written down in fig 1, job breakdown sheet. While progressing towards the application on a lathe machining activity, as per the job breakdown sheet, it was observed that the current method was very complex and required skilled manpower. The maximum time taken was for ID machining 
(Figure-1, 938 seconds \& 6 times) and number of inspections (Figure-1, 6 times). The ID Machining required more time because the operator was not completely aware of how much of the material was to be removed from the ID to meet the exact dimensions of the product. For the material removal, the operator used to take depth of cuts as per his guess, which eventually increased the number of cuts. Due to the more no. of cuts, the operator has to do more inspections between two intermediate cuts with the help of ID measuring GO gauge. So for reducing this ID machining time, the exact material which was actually required to remove from the job was to be calculated using the reference of the outer diameter (OD) of the plate with the help of a vernier calliper. Due to this the number of cuts which were required for machining is reduced and thus reducing the ID machining time. Also, it was observed that the weight of this gauge was $9 \mathrm{KG}$. The numbers of inspections were more too, thus the operator had to use the $9 \mathrm{KG}$ gauge again and again, due to this, there was more fatigue to the operator and eventually it affected the speed of the work. So gauge weight reduction (from $9 \mathrm{~kg}$ to $5 \mathrm{~kg}$ ) was done by boring in handle and making grip using rubber.

In step 1, a job breakdown sheet was made (figure, 1) and as per step 2 questioning was done, based on questioning using ECRS technique some new methods were developed which were proposed in "Proposed JBS JM Sheet" (Table, 2)

As per the proposed method sheet the total number of activities listed were 61 and time taken to complete these activities came 37.13 minutes. As per the job breakdown sheet of existing process (Figure, 1) the number of activities were 91 and time taken was 55 minutes, so Proposed JBS-JM sheet had improvement in terms of total activities and time taken.

\section{Apply New Method}

Improvements are of no use when they are still on paper and not put on to work. In the application phase, the main agenda is to convince the management to put this whole improvement plan into action. All the improvement plans on paper cannot be executed unless the management agrees to do so. For convincing the management, it is very essential for them to know the process of the new method and how it can be helpful in uplifting the productivity. There are 4 steps involved in "Apply the New Method" step, which are as follows:

I. Sell your improvement ideas

II. Get Approval from required areas

III. Implement the change as quickly as possible

IV. Give credits

The improvement proposal sheet (Table, 3) was made with all benefits related to the new methods and was presented to management

Team presented improvement proposal sheet to management, they approved and given a green signal to implement the new process of preforming material removal task on lathe machine. Team arranged the material and did a trial run successfully, the team followed the new proposed method for a month and collected results to check the impact of JM technique in long term.

\section{RESULTS}

After the implementation of new methods for a month, it was seen that the improved method is more productive and easy, compared to the previous one. Tool touch time reduced, setup time reduced and number of cuts and number of inspections were also reduced. Due to reduction of inspection frequency and gauge weight the operators were happy. The material handling of job was reduced due to all jobs being placed at once near the machine. The JM implementation helped to standardize the current method of work. The results were summarized to check which the effectiveness (Table 4- Results of JM)

The results achieved by the usage of Job Methods technique were self-explanatory, the team achieved a significant productivity improvement of $27 \%$ per shift in machining section by reducing number of activities from 91 to 61 to complete one job on one lathe machine. Some of the before and after photos are also shared for better understanding (table 5)

\section{CONCLUSION}

On the basis of the study, it was concluded that the Job Method is the best tool for developing improved methods involving operators and supervisors. Company achieved a significant productivity improvement of $27 \%$ per shift without adding any machine or manpower, this productivity improvement was achieved only by simplifying existing processes (activities and methods). Company understood that JM technique is a simple, systematic, calculated and effective approach to figure out the best possibly suitable methods over the existing methods without compromising on Quality. Customer delivery rate also increased significantly, Company deferred its plan to extend the facility as they discovered hidden capacity. After successful implementation of JM technique in lathe machine Department Company appreciated and awarded the team, also company selected the members from this team and given them a full time responsibility to deploy JM horizontally in other departments. The case study succeeded to prove the point that during COIVD-19, when companies are facing a lot of issues regarding human 
resources, the productivity can be improved by simplification of process without adding any new manpower or machine.

\section{REFERENCES}

Charles R. Allen, (2018), The Instructor: The Man and the Job

Donald A. Dinero, (2005). Training within industry: The foundation of lean. Productivity Press.

Donald A. Dinero (2016), The TWI Facilitator's Guide: How to Use the TWI Programs successfully

Džubáková, M., \& Kopták, M. (2015). Training within industry, Journal for Research and education

Kaizen Institute (India) (2019), [online] available from; <https://www.kaizen.com/learn-kaizen/learningmaterials.html >

Patrick Graupp \& Robert J. (2006) Wrona defined JI in their book "The TWI Workbook: Essential Skills for Supervisors"

Parason machinery (India) (2019), [online] available from; $<$ https://parason.com/about/>

The Training Within Industry Report, 1940-1945: A Record of the Development of Management techniques for Improvement of Supervision, Their Use and the Results. War manpower commission, Bureau of training, Training within industry Service, 1945.

Figure 1 - Job Breakdown Sheet

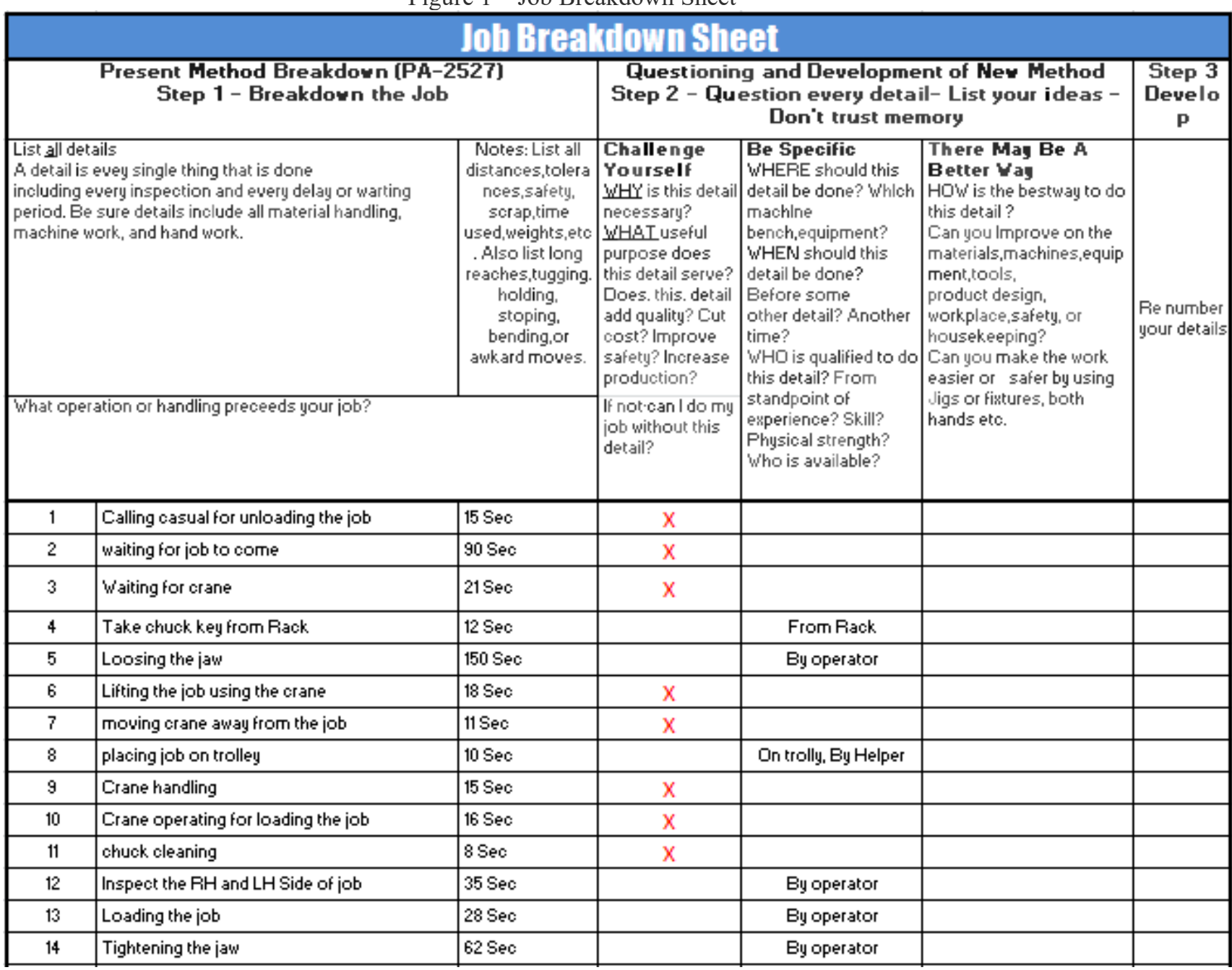




\begin{tabular}{|c|c|c|c|c|c|}
\hline 15 & Waiting for jaw tightening & $24 \mathrm{Sec}$ & $\mathrm{x}$ & & \\
\hline 16 & Tightening the jaw and rotating & $36 \mathrm{Sec}$ & & By operator, Un & \\
\hline 17 & Take dial gauge & $2 \mathrm{Sec}$ & & By operator & \\
\hline 18 & Dial gauge setting & $38 \mathrm{Sec}$ & & By operator & \\
\hline 19 & OD true & $120 \mathrm{Sec}$ & & By operator & \\
\hline 20 & Job rotate and true & $142 \mathrm{Sec}$ & & By operator & \\
\hline 21 & Face true & $195 \mathrm{Sec}$ & & By operator & \\
\hline 22 & Hammering on job for face true & $85 \mathrm{Sec}$ & & By operator & \\
\hline 23 & Again Check and hammering on job & $55 \mathrm{Sec}$ & & By operator & \\
\hline 24 & Hammering on back side of job & $36 \mathrm{Sec}$ & & From Rack & \\
\hline 25 & Take other hammer & $10 \mathrm{Sec}$ & & & \\
\hline 26 & Using both hammer adjust the face & $15 \mathrm{Sec}$ & & By operator & \\
\hline 27 & Hammering the face side of the plate & $18 \mathrm{Sec}$ & & By operator & \\
\hline 28 & Make adjustment in plate & $5 \mathrm{Sec}$ & & By operator & \\
\hline 29 & Check the belt tension & $10 \mathrm{Sec}$ & & On pully & \\
\hline 30 & Tightening belt & $13 \mathrm{Sec}$ & & By operator & \\
\hline 31 & Make adjustment for speed change & $12 \mathrm{Sec}$ & & By operator & \\
\hline 32 & Take screw driver from other operator & $20 \mathrm{Sec}$ & $\mathrm{x}$ & From other operator & \\
\hline 33 & Check ID using gauge & $12 \mathrm{Sec}$ & & & \\
\hline 34 & Moving the hand wheel & $6 \mathrm{Sec}$ & & By operator & \\
\hline 35 & Start machining & $3 \mathrm{Sec}$ & & By operator & \\
\hline 36 & Give feed & $4 \mathrm{Sec}$ & A gear at high & & \\
\hline 37 & 1st Depth of cut & $3 \mathrm{Sec}, 0.3 \mathrm{~mm}$ & & By operator & \\
\hline 38 & ID machining & $186 \mathrm{Sec}$ & & By operator & \\
\hline 39 & Stop the machine & $5 \mathrm{Sec}$ & & By operator & \\
\hline 40 & Moving away tool post & $8 \mathrm{Sec}$ & & By operator & \\
\hline 41 & Take gauge & $4 \mathrm{Sec}, 9 \mathrm{KG}$ & & By operator & $\begin{array}{l}\text { Removal of excess } \\
\text { material inorder to reduce } \\
\text { the weight of gauge }\end{array}$ \\
\hline 42 & checking the ID & $16 \mathrm{Sec}, 9 \mathrm{KG}$ & & By operator & \\
\hline 43 & take out the gauge & $7 \mathrm{Sec}, 9 \mathrm{KG}$ & & By operator & \\
\hline
\end{tabular}




\begin{tabular}{|c|c|c|c|c|c|c|}
\hline 44 & slide the tool post towards job & $6 \mathrm{Sec}$ & & By operator & & \\
\hline 45 & 2nd depth of cut & 3 Sec, $0.3 \mathrm{~mm}$ & $\mathrm{x}$ & & & \\
\hline 46 & ID machining & $183 \mathrm{Sec}$ & $\mathrm{x}$ & & & \\
\hline 47 & Stop the machine & 5 Sec & $\mathrm{x}$ & & & \\
\hline 48 & Moving away tool post & 6 Sec & $\mathrm{x}$ & & & \\
\hline 49 & Take gauge & $4 \mathrm{Sec}, 9 \mathrm{KG}$ & $\mathrm{x}$ & & & \\
\hline 50 & checking the ID & $19 \mathrm{Sec}, 9 \mathrm{KG}$ & $\mathrm{x}$ & & & \\
\hline 51 & take out the gauge & $7 \mathrm{Sec}, 9 \mathrm{KG}$ & $\mathrm{x}$ & & & \\
\hline 52 & slide the tool post towards job & $6 \mathrm{Sec}$ & $\mathrm{x}$ & & & \\
\hline 53 & 3rd depth of cut & 3 Sec, $0.3 \mathrm{~mm}$ & $\mathrm{x}$ & & & \\
\hline 54 & ID machining & $187 \mathrm{Sec}$ & $\mathrm{X}$ & & & \\
\hline 55 & Stop the maching & $5 \mathrm{Sec}$ & $\mathrm{x}$ & & & \\
\hline 56 & Moving away tool post & $7 \mathrm{Sec}$ & $\mathrm{x}$ & & & \\
\hline 57 & Take gauge & $4 \mathrm{Sec}, 9 \mathrm{KG}$ & $\mathrm{x}$ & & & \\
\hline 58 & checking the ID & $17 \mathrm{Sec}, 9 \mathrm{KG}$ & $\mathrm{x}$ & & & \\
\hline 59 & take out the gauge & 7 Sec, 9KG & $\mathrm{X}$ & & & \\
\hline 60 & slide the tool post towards job & $6 \mathrm{Sec}$ & $\mathrm{x}$ & & & \\
\hline 61 & 4th depth of cut & 2 Sec, $0.2 \mathrm{~mm}$ & $x$ & & & \\
\hline 62 & ID machining & $190 \mathrm{Sec}$ & $\mathrm{X}$ & & & \\
\hline 63 & Stop the maching & $5 \mathrm{Sec}$ & $\mathrm{x}$ & & & \\
\hline 64 & Moving away tool post & $9 \mathrm{Sec}$ & $\mathrm{X}$ & & & \\
\hline 65 & Take gauge & 4 Sec, 9KG & $x$ & & & \\
\hline 66 & checking the ID & $16 \mathrm{Sec}, 9 \mathrm{KG}$ & $\mathrm{x}$ & & & \\
\hline 67 & take out the gauge & $7 \mathrm{Sec}, 9 \mathrm{KG}$ & $\mathrm{X}$ & & & \\
\hline 68 & slide the tool post towards job & $6 \mathrm{Sec}$ & $\mathrm{X}$ & & & \\
\hline 69 & 5th depth of cut & 4 Sec, $0.2 \mathrm{~mm}$ & $\mathrm{x}$ & & $\begin{array}{l}\text { Calculating the extra } \\
\text { material to be removed }\end{array}$ & \\
\hline 70 & ID machining & $192 \mathrm{Sec}$ & $\mathrm{x}$ & & & \\
\hline 71 & Stop the machine & 5 Sec & $\mathrm{x}$ & & & \\
\hline
\end{tabular}

\begin{tabular}{|c|c|c|c|c|c|c|}
\hline 72 & Moving away tool post & $8 \mathrm{Sec}$ & $\mathrm{x}$ & & & \\
\hline 73 & Take gauge & $4 \mathrm{Sec}, 9 \mathrm{KG}$ & $\mathrm{X}$ & & & \\
\hline 74 & checking the ID & $18 \mathrm{Sec}, 9 \mathrm{KG}$ & $\mathrm{x}$ & & $\begin{array}{c}\text { Inspection between a } \\
\text { constitutive cut }\end{array}$ & \\
\hline 75 & take out the gauge & $7 \mathrm{Sec}, 9 \mathrm{KG}$ & $\mathrm{X}$ & & & \\
\hline 76 & Gauge passed in ID & $6 \mathrm{Sec}, 9 \mathrm{kG}$ & $\mathrm{x}$ & & & \\
\hline 77 & Place gauge & $8 \mathrm{Sec}, 9 \mathrm{KG}$ & $\mathrm{X}$ & & & \\
\hline 78 & Change tool post setting for facing operation & $48 \mathrm{Sec}$ & & By operator & & \\
\hline 79 & Slide tool post towards job & $8 \mathrm{Sec}$ & & By operator & & \\
\hline 80 & Face operation depth of cut & 2 Sec, $0.8 \mathrm{~mm}$ & & By operator & & \\
\hline 81 & start the machine & 3 Sec & & By operator & & \\
\hline 82 & Face machining & $613 \mathrm{Sec}$ & & By operator & & \\
\hline 83 & Stop the machine & $3 \mathrm{Sec}$ & & By operator & & \\
\hline 84 & Moving away tool post & 5 Sec & & By operator & & \\
\hline 85 & visual inspection & $8 \mathrm{Sec}$ & & By operator & & \\
\hline 86 & Calling casual for unloading the job & $32 \mathrm{Sec}$ & & By operator & & \\
\hline 87 & Waiting for crane & $25 \mathrm{Sec}$ & & By operator & & \\
\hline 88 & Take chuck key from Rack & 6 Sec & & By operator & $\begin{array}{c}\text { Arrangement for placing } \\
\text { chuck key }\end{array}$ & \\
\hline 89 & Loose the jaw & $84 \mathrm{Sec}$ & & By operator & & \\
\hline 90 & Lift job using crane & $18 \mathrm{Sec}$ & & By operator & & \\
\hline \multirow[t]{3}{*}{91} & Put job on trolly & 15 Sec & $\mathrm{X}$ & & & \\
\hline & Total Time For Lathe Machining in min & 55 & & & & \\
\hline & Machining time of 6 cuts (before) in min & 33 & & & & \\
\hline
\end{tabular}


Table 1 -Questions Asking Sequence

\begin{tabular}{|l|l|l|}
\hline Sr. & Question & Detail \\
\hline 1 & Why is it necessary? & Helps to distinguish between necessary and unnecessary. \\
\hline 2 & What is the purpose? & It adds quality or value to a product or service \\
\hline 3 & Where should it be done? & Helps determining the best place to do each detail \\
\hline 4 & When it should be done? & Helps determine the best time to do a job. \\
\hline 5 & Who is the best qualified to do it? & Determines the best person to do it \\
\hline 6 & How is the 'best way' to do it? & Determiners the best way of doing. \\
\hline
\end{tabular}

Table 2 - Proposed JBS -JM Sheet

\section{PROPOSED JBS-JM SHEET}

\begin{tabular}{|c|c|c|}
\hline \multicolumn{2}{|r|}{ Product : 21"RTR, Made By : YVM, PMA, AVC } & \multirow{2}{*}{$\begin{array}{c}\text { Operations: ID, FACING } \\
\text { Time / Notes }\end{array}$} \\
\hline Sr. No. & All Details of proposed JBS Sheet & \\
\hline 1 & Calling the helper & $10 \mathrm{Sec}$ \\
\hline 2 & Bring the crane & $8 \mathrm{Sec}$ \\
\hline 3 & Loose the jaw & $23 \mathrm{Sec}$ \\
\hline 4 & Unloading the job using crane & $20 \mathrm{Sec}$ \\
\hline 5 & Lifting the job using crane & $6 \mathrm{Sec}$ \\
\hline 6 & Put job on trolley & $8 \mathrm{Sec}$ \\
\hline 7 & Loose the jaw & $48 \mathrm{Sec}$ \\
\hline 8 & chuck cleaning & $8 \mathrm{Sec}$, Using brush \\
\hline 9 & Take the job using crane & $10 \mathrm{sec}$ \\
\hline 10 & Loading the job on chuck & $9 \mathrm{sec}$ \\
\hline 11 & Inspect the RH and LH Side of job & $10 \mathrm{Sec}$ \\
\hline 12 & Loading the job & $22 \mathrm{Sec}$ \\
\hline 13 & Tightening the jaw and rotating & $16 \mathrm{Sec}$ \\
\hline 14 & Take dial gauge & $9 \mathrm{Sec}$ \\
\hline 15 & Dial gauge setting & $63 \mathrm{Sec}$ \\
\hline 16 & OD true & $230 \mathrm{Sec}$ \\
\hline 17 & Job rotate and true & $70 \mathrm{Sec}$ \\
\hline 18 & Face true & $121 \mathrm{Sec}$ \\
\hline 19 & Hammering on job for face true & $75 \mathrm{Sec}$ \\
\hline 20 & Hammering on back side of job & $12 \mathrm{Sec}$ \\
\hline 21 & Take other hammer & $6 \mathrm{Sec}$ \\
\hline 22 & Using both hammer adjust the face & $25 \mathrm{Sec}$ \\
\hline 23 & Hammering the face side of the plate & $5 \mathrm{Sec}$ \\
\hline 24 & Check the belt tension & $12 \mathrm{Sec}$ \\
\hline 25 & Make adjustment for speed change & $13 \mathrm{Sec}$ \\
\hline 26 & Tightening belt & $12 \mathrm{Sec}$ \\
\hline 27 & Check OD using vernier & $25 \mathrm{Sec}$ \\
\hline 28 & Check the distance between OD \& ID & $18 \mathrm{Sec}$ \\
\hline 29 & Calculation of ID Allowance & $35 \mathrm{Sec}$ \\
\hline 30 & Moving the hand wheel & $3 \mathrm{Sec}$ \\
\hline 31 & Start machine & $4 \mathrm{Sec}$ \\
\hline 32 & Give feed & $3 \mathrm{Sec}$ \\
\hline 33 & Give required First Depth of cut & $8 \mathrm{Sec}$ \\
\hline 34 & ID machining & $167 \mathrm{Sec}$ \\
\hline 35 & Stop the machine & $5 \mathrm{Sec}$ \\
\hline 36 & Moving tool post away from chuck & $7 \mathrm{Sec}$ \\
\hline 37 & Take gauge & $6 \mathrm{Sec}, 5 \mathrm{Kg}$ \\
\hline 38 & Checking the ID using gauge & $12 \mathrm{Sec}$ \\
\hline 39 & Take out the gauge & $6 \mathrm{Sec}$ \\
\hline 40 & Slide the tool post towards job & $7 \mathrm{Sec}$ \\
\hline 41 & Give final depth of cut & $5 \mathrm{Sec}$ \\
\hline 42 & Start the machine & $4 \mathrm{Sec}$ \\
\hline 43 & ID machining & $176 \mathrm{Sec}$ \\
\hline
\end{tabular}


PROPOSED JBS-JM SHEET

\begin{tabular}{|c|l|l|}
\hline \multicolumn{2}{|c|}{ PROPOSED JBS-JM SHEET } \\
\hline \multicolumn{2}{|c|}{ Product : 21"RTR, Made By : YVM, PMA, AVC } & Operations: ID, FACING \\
\hline Sr. No. & \multicolumn{1}{|c|}{ All Details of proposed JBS Sheet } & \multicolumn{1}{c|}{ Time / Notes } \\
\hline 44 & Stop the machine & $4 \mathrm{Sec}$ \\
\hline 45 & Moving away tool post & $4 \mathrm{Sec}$ \\
\hline 46 & Check ID by gauge & $43 \mathrm{sec}, 5 \mathrm{Kg}$ \\
\hline 47 & Change tool post setting for facing operation & $47 \mathrm{Sec}$ \\
\hline 48 & Slide tool post towards job & $7 \mathrm{Sec}$ \\
\hline 49 & Give depth of cut & $6 \mathrm{Sec}$ \\
\hline 50 & start the machine & $5 \mathrm{Sec}$ \\
\hline 51 & Face machining & $669 \mathrm{Sec}$ \\
\hline 52 & Stop the machine & $3 \mathrm{Sec}$ \\
\hline 53 & Moving away tool post & $7 \mathrm{Sec}$ \\
\hline 54 & Visual inspection & $8 \mathrm{Sec}$ \\
\hline 57 & Loose the jaw & $20 \mathrm{Sec}$ \\
\hline 58 & Bring the crane & $9 \mathrm{Sec}$ \\
\hline 59 & Unloading the job using crane & $32 \mathrm{Sec}$ \\
\hline 60 & Lifting the job using crane & $12 \mathrm{Sec}$ \\
\hline 61 & Put job on trolley & $10 \mathrm{Sec}$ \\
\hline
\end{tabular}

Table 3 - Improvement Proposal Sheet

\begin{tabular}{|c|c|c|c|c|c|}
\hline \multicolumn{6}{|c|}{ Improvement Proposal Sheet } \\
\hline \multicolumn{2}{|c|}{ Department : } & \multirow[t]{2}{*}{ PRODUCTION } & Operations & ID \& FACE & \\
\hline 1 & $\begin{array}{l}1 \\
\text { S Summary } \\
\end{array}$ & & & & \\
\hline \multicolumn{6}{|c|}{$\begin{array}{l}\text { We had worked on } 21 \text { " Rotor machining on lathe, it was observed that the material handling, machining time, } \\
\text { Set up time is more. The waiting time of rotor at drilling section is more. As per proposed method the machining } \\
\text { time and weight of gauge will reduced. }\end{array}$} \\
\hline 2 & \multicolumn{5}{|c|}{ Results ( Proposed $\backslash$ Achieved ) } \\
\hline $\mathbf{S r}$ & & Results & Before & After & Impact Status \\
\hline 1 & \multicolumn{2}{|l|}{ Jobs Per shift } & 8 & 11 & + \\
\hline 2 & \multicolumn{2}{|c|}{ No of activities } & 91 & 61 & + \\
\hline 3 & \multicolumn{2}{|c|}{ Tool Touch time in min } & 33 & 22 & + \\
\hline 4 & \multicolumn{2}{|c|}{ Setup Time in min } & 22 & 15 & + \\
\hline 5 & \multicolumn{2}{|c|}{$\begin{array}{l}\text { Material Handling Movement in meter per } \\
\text { shift }\end{array}$} & 552 & 94 & + \\
\hline 6 & \multicolumn{2}{|c|}{ No of Depth of cuts for ID Machining } & 5 & 2 & + \\
\hline 7 & \multicolumn{2}{|c|}{ No of Gauge Inspections of ID } & 6 & 2 & + \\
\hline 8 & \multicolumn{2}{|c|}{ Gauge Weight in $\mathrm{KG}$} & 9 & 5 & + \\
\hline 3 & \multicolumn{5}{|c|}{ Improvements } \\
\hline SR & \multicolumn{2}{|r|}{ BEFORE } & \multicolumn{3}{|c|}{ AFTER } \\
\hline 1 & \multicolumn{2}{|c|}{ Time required for ID machining is more } & \multicolumn{3}{|c|}{ Time required for ID machining will reduce } \\
\hline 2 & \multicolumn{2}{|c|}{$\begin{array}{l}\text { Operator doing more number of inspection } \\
\text { during machining }\end{array}$} & \multicolumn{3}{|c|}{$\begin{array}{c}\text { Operator doing less number of inspection during } \\
\text { machining }\end{array}$} \\
\hline 3 & \multicolumn{2}{|c|}{ More fatigue to operator due to heavy gauge } & \multicolumn{3}{|c|}{ Less fatigue as weight of gauge is reduced } \\
\hline 4 & \multicolumn{2}{|c|}{ More fatigue in inspection activity } & \multicolumn{3}{|c|}{ Gauge handling is easy } \\
\hline 4 & $\begin{array}{l}\text { Approval: } \\
\text { Production: } \\
\text { Quality : }\end{array}$ & $\begin{array}{l}\text { Y. Mirge } \\
\text { N. Upse }\end{array}$ & $\begin{array}{l}\text { Engineering: } \\
\text { Safety : }\end{array}$ & $\begin{array}{l}\text { G.Deshmukh } \\
\text { P. Gaikwad }\end{array}$ & \\
\hline 5 & Credits: & B. Barate, P. Vetal & Month: & & \\
\hline
\end{tabular}


Table 4- Results of JM in Machining section

\begin{tabular}{|l|l|c|c|}
\hline Sr. & Results & Before & After \\
\hline 1 & No of Jobs Per shift & 8 & 11 \\
\hline 2 & No of activities to complete the job & 91 & 61 \\
\hline 3 & Tool Touch time in min to complete the job & 33 & 22 \\
\hline 4 & Setup Time in min to make one job & 22 & 15 \\
\hline 5 & Material Handling Movement in meter per shift & 552 & 94 \\
\hline 6 & No of Depth of cuts for ID Machining & 5 & 2 \\
\hline 7 & No of Gauge Inspections of ID & 6 & 2 \\
\hline 8 & Gauge Weight in KG & 9 & 5 \\
\hline
\end{tabular}

Table 5-Before and After pictures

\begin{tabular}{|c|c|c|}
\hline S. No. & Before & After \\
\hline \multirow[t]{2}{*}{1} & & \\
\hline & $\begin{array}{l}\text { Material travelling from storage to } \\
\text { Lathe machine one by one }\end{array}$ & Place all jobs near lathe \\
\hline \multirow[t]{2}{*}{2} & & \\
\hline & $\begin{array}{l}\text { No measurement was done. To check } \\
\text { the extra material GO Gauge is used for } \\
6 \text { times }\end{array}$ & $\begin{array}{l}\text { Reduce the machining time by calculating } \\
\text { the material to be removed resulting in less } \\
\text { inspection \& less depth of cuts }\end{array}$ \\
\hline \multirow[t]{2}{*}{3} & Diseras: & \\
\hline & $\begin{array}{c}\text { Gauge weight is more and no grip is } \\
\text { present }\end{array}$ & $\begin{array}{l}\text { Reduction of weight by boring in handle and } \\
\text { making grip using rubber }\end{array}$ \\
\hline
\end{tabular}

